International Journal of Business Management and Economic Review

Vol. 5, No. 01; 2022

ISSN: 2581-4664

\title{
THE EFFECT OF WORKLOAD AND REMUNERATION ON PERFORMANCE WITH JOB SATISFACTION AS A MEDIATION AT MEURAXA HOSPITAL IN BANDA ACEH CITY
}

\author{
Muhammad Ikhlas, Muhammad Adam and Halimatussakdiah \\ Magister Manajemen, Universitas Syiah Kuala, Indonesia \\ http://doi.org/10.35409/IJBMER.2022.3356
}

\begin{abstract}
This study intends to examine the effect of workload and remuneration on performance with job satisfaction as a mediating variable at the Meuraxa Hospital in the city of Banda Aceh. The population was nurses at Meuraxa Hospital, totaling 323 people. Sampling in this study was carried out using the Slovin formula so that a total sample of 179 nurses was obtained. Data were collected using a questionnaire and analyzed using the Structural Equation Modeling (SEM) method. The results of the study prove that workload significantly affects nurse performance, remuneration significantly affects nurse performance, remuneration significantly affects nurse satisfaction, workload significantly affects nurse satisfaction, satisfaction significantly affects nurse performance, satisfaction mediates the effect of workload on nurse performance, and satisfaction mediates the effect of remuneration on Nurse performance. From these results, it is also explained that satisfaction in the model functions as a partial mediator. So these results summarize academically that the model for improving the performance of nurses is a function of workload and remuneration and satisfaction, whereby increasing the adjustment of workload and remuneration will create an increase in the satisfaction of nurses, which in turn will have an impact on increasing their performance. Academically this model contributes to science and serves as a new premise so that further researchers can develop this tested model by adding variables such as nurse leadership and also nursing culture in the hospital.
\end{abstract}

Keyword: Workload, Remuneration, Job Satisfaction, Nurse Performance.

\section{INTRODUCTION}

Meuraxa Hospital located in Banda Aceh City is one of the hospitals owned by the Banda Aceh City Government which has made several changes. In 2015, Meuraxa Hospital implemented Islamic health services and developed a hospital management information system (SIM-RS) in order to improve its services to the community. In 2020 Meuraxa Hospital has a total of 739 employees, both medical and non-medical. Of the 739 employees, the number of medical personnel who proceed as PNS doctors is 55 people, 56 non-civil servants doctors, nurses with civil servant status as many as 91 people, and nurses with non-PNS status as many as 302 people. Of the total medical resources owned by Meuraxa Hospital, more than 50\% of them are non-civil servants. This will certainly greatly affect its performance as a public service institution.

Nurses have a very important role in efforts to improve performance and achieve organizational goals from Meuraxa Hospital. Nurses in hospitals are an important factor in maximizing hospital performance. In carrying out their daily activities, every nurse is always 


\section{International Journal of Business Management and Economic Review}

Vol. 5, No. 01; 2022

ISSN: 2581-4664

required to remain professional in providing services to patients. In addition to being required to always display good performance, every nurse is also required to always have excellent manners in providing services to patients. Every nurse is required to have skills in treating patients. However, it is still often found that there are nurses who do not respect their professional attitude in carrying out their daily tasks. This is known from the fact that there are still some patients who have complaints about the attitude and procedures for the services they receive from nurses in the Meuraxa Hospital that are still unsatisfactory, especially during this COVID-19 pandemic. Many patients complain that the nurses are less than optimal in providing services. This is because of the fear of all medical personnel contracting the pandemic virus to them.

Apart from the factors mentioned above, several other factors affect the performance of nurses at the Meuraxa Aceh Hospital as revealed by (Perera, Khatibi, Navaratna, \& Karuthan, 2014) namely by education, motivation, work discipline, income level, and job satisfaction. Job satisfaction must be owned by every nurse, it is necessary for nurses to feel comfortable and not pressured in serving patients. Job satisfaction can also be generated from several things, one of the reasons that can lead to job satisfaction for nurses is a love for their work, so loving the work we are doing will get a certain satisfaction that cannot be explained in words because it can only be felt. Moreover, the work currently being done is a hobby of the nurse, because there is a sentence from a wise person: "doing a hobby is fun and the most fun time is when a hobby can make money". It can be said that the job satisfaction of nurses at the Meuraxa Hospital is good.

One of the factors that affect the performance of nurses and nurse job satisfaction is the workload factor. Based on the results of communication with nurses at the Meuraxa Hospital, they have working hours per shift and are divided into 3 shifts, starting at 08:00 am - 2:00 pm, then 2:00 pm - 8:00 pm, and at 8:00 pm to 08:00 am the next day. The shift schedule that is a little inconvenient for the nurses is during the last shift, which is 8:00 pm - 08:00 am. Because nurses have to stay up all night to look after patients who are being treated and of course their workload increases. Therefore nurses must have a good adaptation process in every situation in the workplace such as a good analytical process to complete their duties optimally. With a surge in patients such as the Covid-19 pandemic, the workload of nurses has also increased, starting from the increased working hours in caring for patients, then also the mental burden of fatigue and also the psychological burden of fear of transmitting diseases to them.

Another factor that has an influence on job satisfaction and has an impact on the performance of nurses is remuneration. Many experts reveal that remuneration has an important role in influencing job satisfaction. (Veithzal Rivai \& Sagala, 2014) explains that a person can act inclined because of the expectation of the results to be obtained. Giving remuneration for every effort will also increase job satisfaction in nurses, especially in recent months there has been financial assistance from the Health Office specifically for nurses who treat Covid-19 patients, in other words, remuneration is considered important.

\section{LITERATURE STUDY}

\section{Employee Performance}

(Engko, 2008) states individual performance as individual work performance which is regulated based on standards or criteria set by an organization. Meanwhile (Veizal Rivai \& Mukti, 2018) Disclosing performance is a real behavior that is displayed by everyone as work performance produced by employees following their role in the company. according to (Perera et al., 2014), 


\section{International Journal of Business Management and Economic Review}

Vol. 5, No. 01; 2022

ISSN: 2581-4664

Performance is the result of work achieved by a person in carrying out his duties on skills, efforts, and opportunities.

Many factors or variables affect the performance of employees or employees in an organization. As stated by. according to (Mathis \& Jackson, 2019), factors that affect performance are ability, motivation, support received, the existence of the work done, and the relationship with the organization. according to (Robbins \& Judge, 2017) Employee performance can be measured using indicators, namely Quality, Quantity, Punctuality, Effectiveness, Independence, and Work Commitment. Meanwhile (Wibowo, 2016) mentions that performance measurement can be done using indicators of productivity, timeliness, cycle time, resource utilization, and benefits. In this study, in measuring performance using indicators as expressed by the two experts.

\section{Job satisfaction}

Job satisfaction is an employee's evaluation of feelings of pleasure or displeasure, satisfied or dissatisfied in carrying out work (Veithzal Rivai \& Sagala, 2014). According to (Liu \& Lo, 2018) Job satisfaction is an emotional attitude that is pleasant and loves his job. (Kreitner \& Kinicki, 2013) express job satisfaction, namely effectiveness or emotional response to various aspects of work.

According to (Robbins \& Judge, 2012) 21 factors determine job satisfaction, namely 1) autonomy and freedom, 2) career benefits, 3) opportunities for advancement, 4) career development opportunities, 5) compensation, 6) communication between nurses and management, 7) work contribution to organizational goals. , 8) feeling of security in the work environment, 9) flexibility to balance life and work issues, 10) job security, 11) job-specific training, 12) management recognition of performance, 13) meaning of work, 14) networking, 15) opportunities for use of skills or expertise, 16) organizational commitment to development, 17) overall corporate culture, 18) nurse-to-person relationships, 19) relationships with direct supervisors, 20) the work itself, and 21) job diversity.

\section{Workload}

The workload is a comparison of the ability of nurses with job demands (Zaki \& Marzolina, 2016). Workload analysis is a number of activities using job analysis techniques, workload analysis techniques, or other management techniques within a certain period to obtain information about the work efficiency of an organizational unit (Cain, 2007);(Zhang et al., 2019). In this study, the measurement of workload uses indicators adopted from (Tarwaka, 2019) and the Decree of the Minister of Administrative Reform No: KEP/75/M.PAN/7/2004 namely effective working hours, educational background, type of work given, working time, body invoice.

\section{Remuneration}

(Ardana, Mujiati, \& Utama, 2012) states that remuneration is all remuneration in the form of money, goods, or pleasure provided by the company to employees for the performance contributed to the company. According to (Pora, 2011) remuneration is all income in the form of money, goods directly or indirectly received by nurses in return for services provided to the company. According to (Subekhi \& Jauhar, 2012) remuneration is any form of award given to nurses in return for their contributions to the organization.

(Veithzal Rivai \& Sagala, 2014) explains that remuneration is a substitute for services 
International Journal of Business Management and Economic Review

Vol. 5, No. 01; 2022

ISSN: 2581-4664

received by nurses at the company. Opinion of (Dessler, 2003) regarding remuneration, it is in the form of payment or compensation for work from the company. Remuneration indicators refer to theory (Veithzal Rivai \& Sagala, 2014) are : 1) salary, 2) incentives, 3) insurances. Whereas (Pora, 2011) mentions remuneration measurement includes salary, incentives, benefits, bonuses, and allowances.

\section{Conceptual Framework}

The conceptual framework of this research can be described as follows :

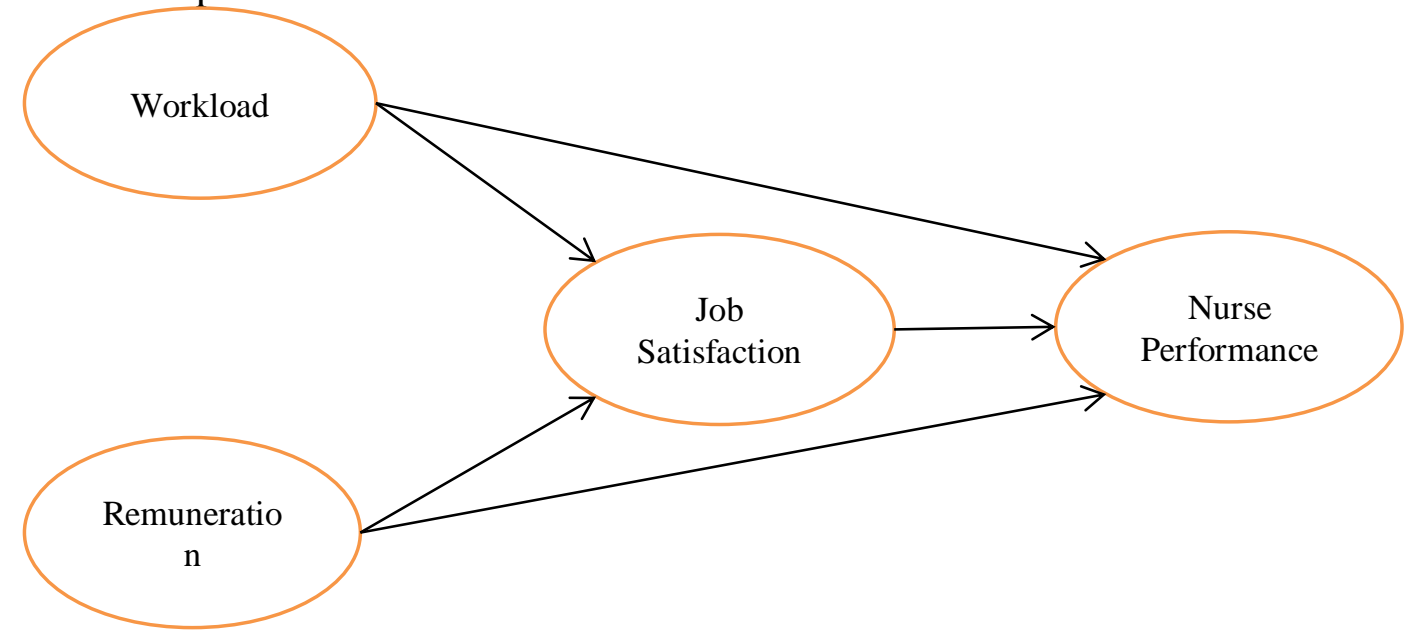

Figure 1. Conceptual Framework

H1: workload affects nurse job satisfaction

$\mathrm{H} 2$ : work remuneration affects job satisfaction

H3: workload affects the nurse performance

H4: Work remuneration affects nurse performance

$\mathrm{H}$ : job satisfaction affects nurse performance

H6: workload affects nurse performance which is mediated by job satisfaction

H7: Job remuneration affects nurse performance mediated by job satisfaction

\section{RESEARCH METHOD}

This study was conducted at Meuraxa Hospital in Banda Aceh City, while the object of the study was the effect of workload and remuneration on performance with job satisfaction as a mediating variable at Meuraxa Hospital. The population was nurses at Meuraxa Hospital, totaling 323 people. The determination of the number of samples in this study was identified by Slovin so that a sample of 179 nurses was obtained. The data collected for analysis includes primary and secondary data. Primary data were collected by distributing questionnaires to nurses at the Meuraxa Hospital. While the secondary data was obtained from the data from the administration section of the Meuraxa Hospital.

Measurement of the answers to the questionnaire using a Likert scale. The Likert scale will produce ordinal data which can measure attitudes, opinions, and perceptions of people or groups of people who are respondents in this study. For testing the direct hypothesis using the AMOS SEM application and for testing the indirect hypothesis using the help of a Sobel 
International Journal of Business Management and Economic Review

Vol. 5, No. 01; 2022

ISSN: 2581-4664

calculator with job satisfaction as a mediator variable. So that mathematically the causal relationship between the constructs in the study can be stated as follows:

$\eta=\gamma 1.1 \xi 1+\gamma 1.2 \xi 2+\zeta 1$

$\eta=\gamma 2.1 \xi 1+\gamma 2.2 \xi 2+\beta 21 \eta 2+\zeta 2$

or:

Job Satisfaction $\quad=\quad \gamma 11$ workload $+\gamma 12$ remuneration $+\zeta 1$

Nurse Performance $\quad=\quad \gamma 21$ workload $+\gamma 12$ remuneration $+\beta 21$ job satisfaction $+\zeta 2$

\section{RESULT}

\section{Hypothesis Testing}

The results of hypothesis testing are presented in the following picture.

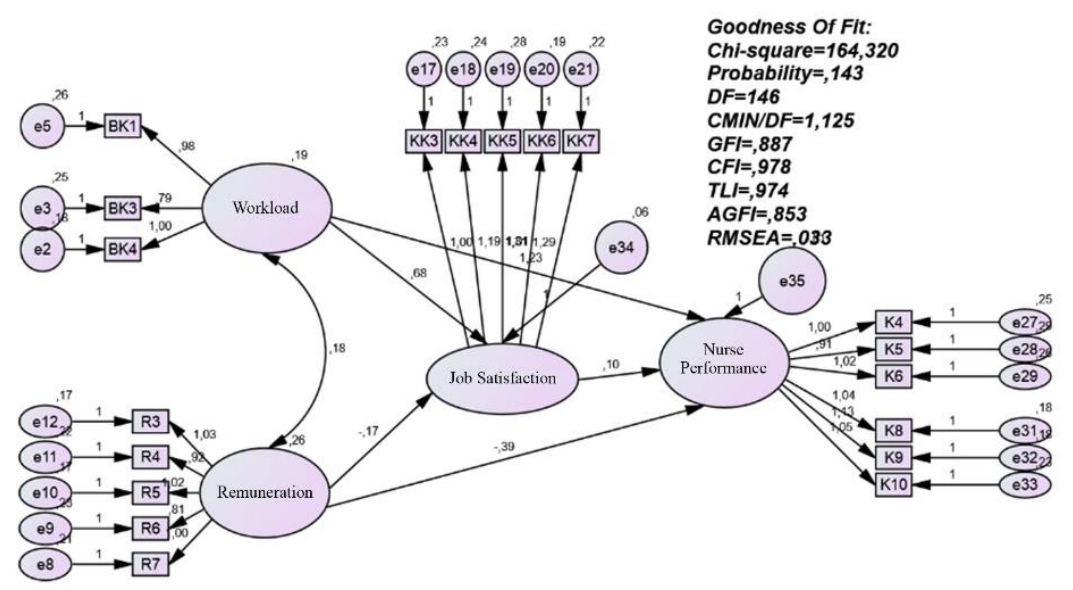

Figure 2. Structural Model Test

From the results of the full SEM model, the results of direct hypothesis testing are obtained as presented in table 1 below:

Table 1. Results of Direct Effect Test

\begin{tabular}{|lll|l|l|l|l|l|l|}
\hline & & & Estimate & Standardized & S.E. & C.R. & P & Label \\
\hline $\mathrm{Z}$ & $<---$ & $\mathrm{X} 2$ & .204 & .293 & .101 & 2.031 & .042 & par_10 \\
\hline $\mathrm{Z}$ & $<---$ & $\mathrm{x} 1$ & .292 & .387 & .120 & 2.421 & .015 & par_11 \\
\hline $\mathrm{Y}$ & $<---$ & $\mathrm{x} 1$ & .415 & .541 & .136 & 3.049 & .002 & par_8 \\
\hline $\mathrm{Y}$ & $<---$ & $\mathrm{X} 2$ & .261 & .368 & .113 & 2.323 & .020 & par_9 \\
\hline $\mathrm{Z}$ & $<---$ & $\mathrm{Y}$ & .612 & .601 & .183 & 3.338 & $* * *$ & par_12 \\
\hline
\end{tabular}

Source: Processed data (2021)

The results of the analysis show that workload and remuneration significantly affect the performance of nurses with satisfaction as a mediator variable. It will be discussed further as follows: 
International Journal of Business Management and Economic Review

Vol. 5, No. 01; 2022

ISSN: 2581-4664

1. Workload effect on job satisfaction

The H1 test reveals that workload on job satisfaction has an effect of 0.415 , critical ratio (C.R) of $3.049>1.967$, and a significant level of $0.002<0.05$. These results explain that $\mathrm{H} 1$ is accepted, namely, the workload significantly affects the job satisfaction of nurses. The results also explain that if the workload increases by 1 point, the performance behavior will increase by 0.541 points. When the workload is high and they manage to complete the job well, there will be a feeling of satisfaction with the success of completing the work. The results of this study are following the study (Setyawan \& Kuswati, 2006) which shows that workload has a significant positive effect on job satisfaction.

2. Remuneration effect on job satisfaction

The $\mathrm{H} 2$ test explains that remuneration on job satisfaction has an effect of 0.261 , a critical ratio (C.R) of $2.323>1.967$, and a significant level of $0.020<0.05$. These results explain that $\mathrm{H} 2$ is accepted, namely remuneration. The results also explain that if the remuneration increases by 1 point, the performance will increase by 0.368 points. The remuneration system is a system that accommodates a company's rewards for performance. Based on the results of this study indicate that the higher the value of the rewards received, the more satisfied the nurses are with the rewards received with the remuneration pattern. The results of this study follow (Yang, Miao, Zhu, \& Sun, 2008) reported that there is an optimistic relationship between remuneration and job satisfaction. Salary shows a direct effect on individual job satisfaction. There is a strong positive relationship between remuneration and job satisfaction (Perera et al., 2014) which shows that if nurses' remuneration increases, their job satisfaction with work will also increase, following previous research.

3. Workload effect on performance

The H3 test illustrates that the workload on job satisfaction has an effect of 0.292 , the critical ratio $(\mathrm{C} . \mathrm{R})$ is $2.421>1.967$, and a significant level of $0.015<0.05$. These results explain that $\mathrm{H} 3$ is accepted, namely, the workload significantly affects the job satisfaction of nurses. This also explains that if the behavior of the workload increases by 1 point, then job satisfaction will increase by 0.387 points. A positive increase in workload will lead to an increase in performance because nurses are used to the given workload so that they become accustomed to being in a high workload. A high workload can also stimulate nurses to be even more active in improving their performance. This result is following the study (Artadi, 2014) which proves that workload can have a positive impact on performance.

4. Remuneration effect on performance

The $\mathrm{H} 4$ test shows that remuneration on job satisfaction has an effect of 0.204 , the critical ratio (C.R) is $2.031>1.967$, and a significant level of $0.042<0.05$. These results state that $\mathrm{H} 4$ is accepted, that is, remuneration has a significant effect on nurse job satisfaction. It also explains that if the remuneration increases by 1 point, then job satisfaction will increase by 0.293 points. So it is hoped that the remuneration is really appropriate following the needs of the nurses so that the results obtained are also as expected. The results of a similar study were also found (Vidianingtyas \& Putri, 2014) where it was found that remuneration partially positively and significantly affects performance.

5. Job satisfaction effect on performance

The $\mathrm{H} 5$ test shows that job satisfaction on performance has an effect of 0.612 , critical ratio (C.R) of 3.338> 1.967, and a significant level of $0.000<0.05$. These results state that $\mathrm{H} 5$ is 


\section{International Journal of Business Management and Economic Review}

Vol. 5, No. 01; 2022

ISSN: 2581-4664

accepted, that is, job satisfaction significantly affects the performance of nurses. It also explains that if job satisfaction increases by 1 point, then performance will increase by 0.601 points. Nurses who are satisfied with the things they get from the hospital will be able to improve performance. A person's performance can be influenced by several factors and one of them is the satisfaction factor. The higher the satisfaction felt by nurses, the higher the performance. The results of this study are following the study (Bowling, 2007), who found that the higher the job satisfaction felt by nurses, the higher the performance. This result is also in line with the study of (Perera et al., 2014) and (Yang et al., 2008) stated that job satisfaction has a positive effect on performance.

\section{Indirect Hypothesis Testing}

1. Workload effect on nurse performance through job satisfaction

According to (Sekaran \& Bougie, 2016), mediating variable is an intermediary variable. The mediation test is used in this study to prove the role of job satisfaction as a mediating variable, which functions to mediate the relationship between workload and remuneration variables on performance.

The proof of the indirect effect hypothesis is carried out using the approach (Baron \& Kenny, 1986) and Sobel Test. which can be seen in Table 2 below:

\section{Table 2. Mediation effect of $\mathrm{H6}$}

\begin{tabular}{|c|c|c|c|c|c|c|c|c|}
\hline \multicolumn{9}{|c|}{ Coefficients $^{a}$} \\
\hline \multirow[b]{2}{*}{ Model } & & \multicolumn{2}{|c|}{ Unstandardized Coefficients } & \multirow{2}{*}{$\begin{array}{c}\text { Standardized } \\
\text { Coefficients } \\
\text { Beta }\end{array}$} & \multirow[b]{2}{*}{$t$} & \multirow[b]{2}{*}{ Sig. } & \multicolumn{2}{|c|}{ Collinearity Statistics } \\
\hline & & $\mathrm{B}$ & Std. Error & & & & Tolerance & VIF \\
\hline \multirow[t]{2}{*}{1} & (Constant) & 11,628 & 2,722 & & 4,273 &, 000 & & \\
\hline & Beban_Kerja & 1,005 &, 097 & ,615 & 10,378 &, 000 & 1,000 & 1,000 \\
\hline \multirow[t]{3}{*}{2} & (Constant) & 416 & 3,024 & & 137 & 891 & & \\
\hline & Beban_Kerja & 664 & ,103 & ,407 & 6,477 & .000 & ,728 & 1,373 \\
\hline & Kepuasan_Kerja &, 556 & ,087 & .400 & 6,375 &, 000 &, 728 & 1,373 \\
\hline
\end{tabular}

a. Dependent Variable: Kinerja

From the results of the regression analysis in table 2 , it is identified that in model 1 there is a significant unidirectional relationship between workload variables on performance, which is indicated by $1=0.615$ and Sig $<0.05$. When the relationship between workload and performance included the mediating variable in model 2 , namely job satisfaction, it also showed a significant relationship $(\beta 2=0.407, \mathrm{p}<0.05)$. The picture also informs about the change in the value of the first workload which was previously 0.615; after entering the mediating variable, the value becomes 0.407 . Based on the results above, it can be explained that the job satisfaction variable has a role as partial mediation. This is because the relationship between workload variables and performance variables before and after the inclusion of the mediating variable is equally significant. This supports the hypothesis that has been put forward in this study.

Furthermore, the Sobel test developed by (Sobel, 1982). The following is a test of the mediating effect of job satisfaction variables which can be explained as follows: 
International Journal of Business Management and Economic Review

Vol. 5, No. 01; 2022

ISSN: 2581-4664

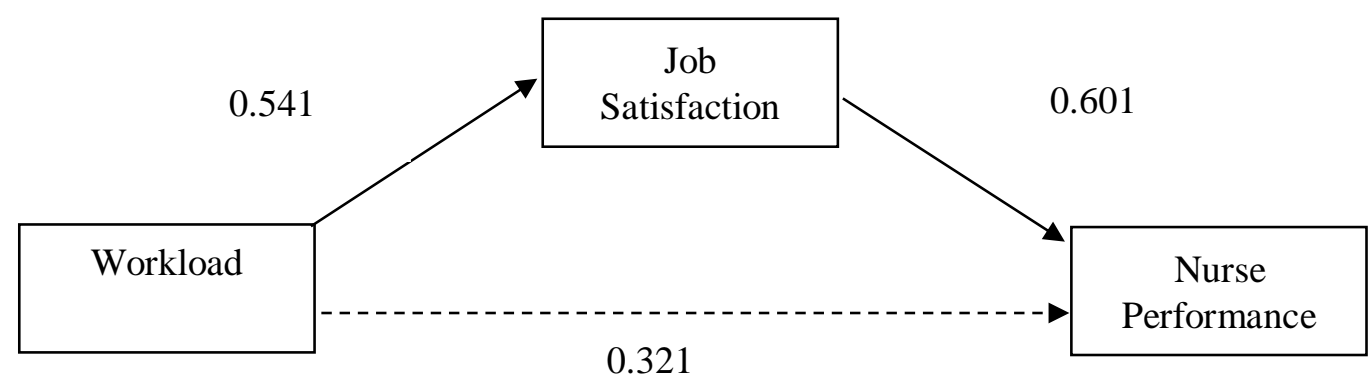

Figure 3. The Mediaton Effect of $\mathrm{Ht}$

Based on Figure 3 above, the result of calculating the p-value from Sobel test is 0.024 (< 0.05 ). These results indicate that there is an indirect effect between workload on performance. Then the hypothesis H6 is accepted, namely, job satisfaction mediates the relationship between workload on the performance of nurses in Meuraxa Hospital.

The results of testing hypothesis 6 reveal that job satisfaction mediates the relationship between workload and nurse performance. When nurses are satisfied in their work, even though they get a lot of workloads, it can be a stimulus for nurses to be able to increase their performance. So that job satisfaction can mediate the relationship between workload and the performance of nurses. These results were also found in the study (Vidianingtyas \& Putri, 2014) who concluded that job satisfaction significantly mediates the effect of workload on performance.

2. Remuneration effect on Nurse Performance through Job Satisfaction

Furthermore, it will explain the effect from before the mediation effect to after the mediation effect (job satisfaction) with the Baron and Kenny approach among the remuneration variables on performance which can be seen in table 3 below.:

Table 3. The Mediation Effect of $\mathbf{H 7}$

\begin{tabular}{|c|c|c|c|c|c|c|c|c|}
\hline \multicolumn{9}{|c|}{ Coefficients $^{a}$} \\
\hline \multirow{2}{*}{\multicolumn{2}{|c|}{ Model }} & \multicolumn{2}{|c|}{ Unstandardized Coefficients } & \multirow{2}{*}{$\begin{array}{c}\begin{array}{c}\text { Standardized } \\
\text { Coefficients }\end{array} \\
\text { Beta }\end{array}$} & \multirow[b]{2}{*}{$t$} & \multirow[b]{2}{*}{ Sig. } & \multicolumn{2}{|c|}{ Collinearity Statistics } \\
\hline & & $B$ & Std. Error & & & & Tolerance & VIF \\
\hline \multirow[t]{2}{*}{1} & (Constant) & 15,745 & 2,433 & & 6,471 &, 000 & & \\
\hline & remunerasi &, 544 &, 055 &, 598 & 9,927 &, 000 & 1,000 & 1,000 \\
\hline \multirow[t]{3}{*}{2} & (Constant) & 1,475 & 2,936 & & 502 & ,616 & & \\
\hline & remunerasi &, 365 &, 054 & ,402 & 6,702 &, 000 & ,789 & 1,268 \\
\hline & Kepuasan_Kerja &, 594 &, 083 & .427 & 7,133 & .000 &, 789 & 1,268 \\
\hline
\end{tabular}

a. Dependent Variable: Kinerja

Based on the results of the regression analysis in table 3, it is identified that in model 1 there is a significant (positive) unidirectional relationship between the remuneration variables on performance, which is indicated by $1=0.598$, and $\mathrm{Sig}<0.05$. When the relationship between remuneration and performance included the mediating variable in model 2 , namely job satisfaction, it also showed a significant relationship $(\beta 2=0.402, p<0.05)$. The description also informs about the change in the value of the first remuneration which was previously 0.598 ; after entering the mediating variable, the remuneration value becomes 0.402 . Based on these results, it can also be explained that the job satisfaction variable has a role as partial mediation (Partial 


\section{International Journal of Business Management and Economic Review}

Vol. 5, No. 01; 2022

ISSN: 2581-4664

Mediation). This is because the relationship between remuneration variables and performance variables before and after the inclusion of the mediating variable is equally significant. This supports the hypothesis that has been put forward in this study.

The following is the test of the mediating effect of the satisfaction variable carried out with the Sobel Test procedure which can be explained as follows:

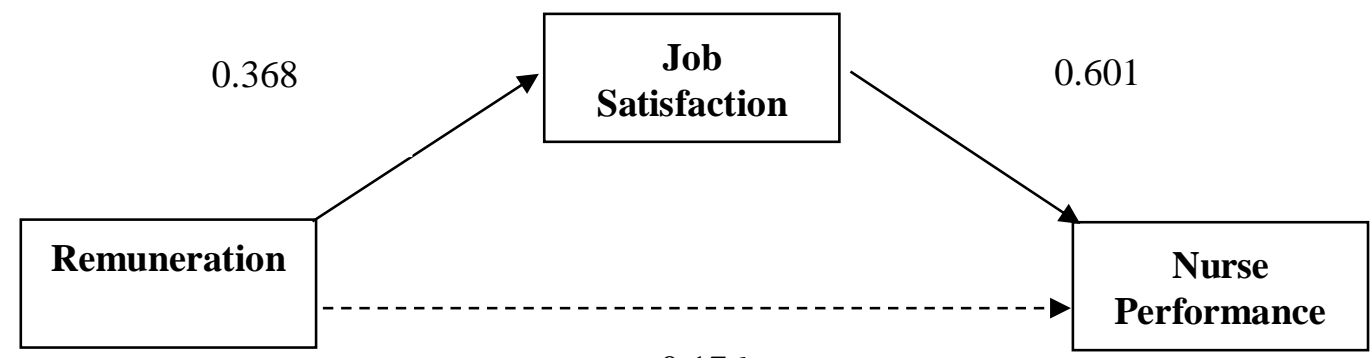

0.176

Figure 4. The Mediation Effect of H7

Based on Figure 4 above, the result of calculating the p-value from the Sobel test is 0.047 $(<0.05)$. These results indicate that there is an indirect effect between remuneration on performance. So the hypothesis $\mathrm{H} 7$ is accepted, namely, job satisfaction mediates the relationship between remuneration and nurse performance. This explains that if the remuneration given is good, it can increase job satisfaction and it can also improve performance. This is following the study (Ristiyani, 2020) which concludes that job satisfaction can mediate between remuneration variables on performance.

\section{CONCLUSION}

The results of the study on nurses at Meuraxa Hospital prove that workload significantly affects nurse performance, remuneration significantly affects nurse performance, remuneration significantly affects nurse job satisfaction, workload significantly affects nurse satisfaction, satisfaction significantly affects nurse performance, satisfaction mediates the effect of workload on nurse performance, and Satisfaction mediates the effect of remuneration on nurse performance. From these results, it is also explained that satisfaction with the model functions as a partial mediator. So these results summarize academically that the model for improving the performance of nurses is a function of workload and remuneration and satisfaction, whereby increasing the adjustment of workload and remuneration will create an increase in the satisfaction of nurses, which in turn will have an impact on increasing their performance. Academically this model contributes to science and serves as a new premise so that further researchers can develop this tested model by adding variables such as nurse leadership and also nursing culture in the hospital.

This model can also contribute as a reference for practitioners. The results of this study recommend to the Meuraxa Hospital to be able to increase the number of workers in the nursing field, of course, so that nurses do not experience excessive workloads due to the inadequate number of nurses. In addition, the Meuraxa Hospital is also expected to be able to provide training to improve the ability of nurses. The Meuraxa Hospital Banda Aceh must also pay attention to the salaries and benefits provided to nurses, where the amount of salary allowances given must be in 


\section{International Journal of Business Management and Economic Review}

Vol. 5, No. 01; 2022

ISSN: 2581-4664

accordance with the workload they get so that the lives of nurses are more secure so they can focus on improving performance.

\section{REFERENCES}

Ardana, I. K., Mujiati, N. W., \& Utama, I. W. M. (2012). Manajemen sumber daya manusia. Yogyakarta: Graha Ilmu.

Artadi, F. F. (2014). Pengaruh Kepuasan Kerja Dan Beban Kerja Terhadap Kinerja Karyawan Pada PT. Merapi Agung Lestari. Universitas Negeri Yogyakarta.

Baron, R. M., \& Kenny, D. A. (1986). The moderator-mediator variable distinction in social psychological research: Conceptual, strategic, and statistical considerations. Journal of Personality and Social Psychology, 51(6), 1173-1182. https://doi.org/10.1037//00223514.51.6.1173

Bowling, N. A. (2007). Is the job satisfaction-job performance relationship spurious? A metaanalytic examination. Journal of Vocational Behavior, 71(2), 167-185. https://doi.org/https://doi.org/10.1016/j.jvb.2007.04.007

Cain, B. (2007). A Review of the Mental Workload Literature. Toronto, Canada.

Dessler, G. (2003). Manajemen Sumber Daya Manusia. Jakarta: PT Indeks.

Engko, C. (2008). engaruh Kepuasan Kerja Terhadap Kinerja Individual Dengan Self Esteem dan Self Efficacy Sebagai Variabel Intervening. Jurnal Bisnis Dan Akuntans, 10(1).

Kreitner, R., \& Kinicki, A. J. (2013). Perilaku Organisasi Bk.2 (9th ed.). Jakarta: Salemba Empat.

Liu, H.-L., \& Lo, V. (2018). An integrated model of workload, autonomy, burnout, job satisfaction, and turnover intention among Taiwanese reporters. Asian Journal of Communication, 28(2), 153-169. https://doi.org/https://doi.org/10.1080/01292986.2017.1382544

Mathis, R. L., \& Jackson, J. H. (2019). Human Resource Management: Personnel Human Resource Management (Ed. 15). USA: Harvard Business Review.

Perera, G. D. N., Khatibi, A., Navaratna, N., \& Karuthan. (2014). Job Satisfaction And Job Performance Among Factory Employees In Apparel Sector. Asian Journal Of Management Sciences \& Education, 3(1), 96-104.

Pora, A. de. (2011). Remunerasi: Kompensasi \& Benefit. Jakarta: Rana Pustaka.

Ristiyani, F. (2020). Pengaruh Remunerasi, Disiplin Kerja dan Beban Kerja terhadap Kinerja Karyawan dengan Kepuasan Kerja Sebagai Variabel Intervening pada BNI Syariah KC Semarang. Fakultas Ekonomi dan Bisnis Islam, Institut Agama Islam Negeri Salatiga.

Rivai, Veithzal, \& Sagala, E. J. (2014). Manajemen Sumber Daya Manusia untuk Perusahaan: Dari Teori ke Praktik (3rd ed.). Jakarta: Rajawali Pers.

Rivai, Veizal, \& Mukti, A. G. (2018). Performance Appraisal Cara Tepat dan Mudah Mengukur dan Menilai Kinerja Karyawan dalam Perusahaan (Edisi Keti). Depok: PT. RajaGrafindo Persada.

Robbins, S. P., \& Judge, T. A. (2012). Organizational Behavior (15th ed.; S. Yagan, Ed.). San Diego: Pearson.

Robbins, S. P., \& Judge, T. A. (2017). Essential of Organisational Behaviour (14th ed.). New Jersey: Pearson.

Sekaran, U., \& Bougie, R. (2016). Research Methods For Business: A Skill Building Approach (7th ed.). New Jersey: Wiley.

Setyawan, A. A., \& Kuswati, R. (2006). Teknologi Informasi Dan Reposisi Fungsi Manajemen 
International Journal of Business Management and Economic Review

Vol. 5, No. 01; 2022

ISSN: 2581-4664

Sumber Daya Manusia. Jurnal Manajemen Dan Bisnis, 6(4), 115-123.

Sobel, M. E. (1982). Asymptotic Confidence Intervals for Indirect Effects in Structural Equation Models. Sociological Methodology, 290-321. https://doi.org/https://doi.org/10.2307/270723

Subekhi, A., \& Jauhar, M. (2012). Pengantar Manajemen Sumber Daya Manusia (MSDM). Jakarta: Prestasi Pustakaraya.

Tarwaka. (2019). Ergonomi Industri Dasar Dasar Ergonomi Dan Aplikasi Di Tempat Kerja. Solo: Harapan Pers.

Vidianingtyas, R. N., \& Putri, W. H. (2014). Pengaruh Kompensasi, Kepuasan Kerja, Motivasi Kerja Dan Gaya Kepemimpinan Terhadap Kinerja Karyawan Pada Perusahaan Jasa Catering Di Daerah Istimewa Yogyakarta. Efektif. Jurnal Bisnis Dan Ekonomi, 5(1), 99-110.

Wibowo. (2016). Manajemen Kinerja (kelima). Jakarta: PT. Rajagrafindo Persada.

Yang, H., Miao, D., Zhu, X., \& Sun, Y. (2008). The Influence of a Pay Increase on Job Satisfaction: a Study with the Chinese Army. Social Behavior and Personality An International Journal, 36(10), 1333-1339. https://doi.org/10.2224/sbp.2008.36.10.1333

Zaki, H., \& Marzolina. (2016). Pengaruh Beban Kerja dan Kompensasi terhadap Turnover Intention melalui Kepuasan Kerja Pada Karyawan PT. Adira Quantum Multifinance Cabang Pekanbaru. Jurnal Tepak Manajemen Bisnis, 8(3), 1-23.

Zhang, L., Fan, C., Deng, Y., Lam, C. F., Hu, E., \& Wang, L. (2019). Exploring the interpersonal determinants of job embeddedness and voluntary turnover: A conservation of resources perspective. Human Resource Management Journal, 29(3), 413-432. https://doi.org/https://doi.org/10.1111/1748-8583.12235 